\title{
Religiusitas, kebermaknaan hidup, dukungan sosial dan penyesuaian diri narapidana
}

\author{
Candra Sukmanawatia,1, Wiwin Dinar Prastitib,2* \\ a,bFakultas Psikologi, Universitas Muhammadiyah, Surakarta \\ ${ }^{1}$ sukmanawati1981@gmail.com; *2wdp206@ums.ac.id \\ *Correspondent Author
}

KATAKUNCI ABSTRAK

dukungan sosial; kebermaknaan hidup; penyesuaian diri; religiusitas

Setiap individu senantiasa dihadapkan pada situasi yang terus berubah. Tidak terkecuali seorang narapidana yang harus menyesuaikan diri di lingkungan barunya. Penyesuaian diri perlu dilakukan oleh setiap individu demi tercapainya keharmonisan antara diri dan tuntutan lingkungan. Tujuan penelitian ini untuk menguji apakah ada korelasi antara religiusitas, kebermaknaan hidup, dukungan sosial dan penyesuaian diri narapidana. Metode yang digunakan pada penelitian ini menggunakan metode kuantitatif desain korelasi. Subjek penelitian ini memiliki karakteristik berstatus narapidana Rumah Tahanan (Rutan) Kelas I Surakarta, Jawa Tengah sejumlah 246 orang dengan menggunakan studi populasi. Alat penumpulan data menggunakan skala religiusitas, kebermaknaan hidup, dukungan sosial dan penyesuaian diri narapidana. Analisis data yang digunakan regresi berganda dengan SPSS 21 for windows. Hasil penelitian menyimpulkan (1) terdapat korelasi yang sangat signifikan antara religiusitas, kebermaknaan hidup, dan dukungan sosial dengan penyesuaian diri. (2) terdapat korelasi positif antara religiusitas dengan penyesuaian diri. (3) terdapat korelasi positif antara kebermaknaan hidup dengan penyesuaian diri. (4) terdapat korelasi positif antara dukungan sosial dengan penyesuaian diri. Selanjutnya sumbangan efektif (SE) religiusitas, kebermaknaan hidup dan dukungan sosial pada penyesuaian diri, sebesar 60,6\%.

\section{Religiosity, meaning of life, social support and adjustment of prisoners}

\section{KEYWORDS}

adjustment; meaningfulness of life; religiosity; social support
Every individual always be faced with situations that are constantly changing. There is no exception for an inmate who must adjust to his new environment. Self-adjustment needs to be done by each individual in order to achieve harmony between self and environmental demands. The purpose of this study is to test whether there is a correlation between religiosity, meaningfulness of life, social support and adjustment of prisoners. The method used in this study uses a quantitative method of correlation design. The subjects in this study have the characteristics of being inmates at the Class I Detention Center (Rutan) Surakarta, Central Java, with a total of 246 people using a population study. The data collection tool uses a scale of religiosity, meaningfulness of life, social support and adjustment of prisoners. Data analysis used multiple regression with SPSS 21 for windows. The results of the study concluded (1) there is a very significant correlation between religiosity, meaningfulness of life, and social support with selfadjustment. (2) there is a positive correlation between religiosity and 
self-adjustment. (3) there is a positive correlation between the meaning of life and adjustment. (4) there is a positive correlation between social support and adjustment. Furthermore, the effective contribution (SE) of religiosity, meaningfulness of life and social support to self-adjustment is $60.6 \%$.

This is an open-access article under the CC-BY-SA license.

\section{Pendahuluan}

Setiap individu senantiasa dihadapkan pada situasi yang terus berubah, dan membutuhkan usaha untuk mengatasi ketegangan, menghindari konflik dan frustrasi. Usaha dalam rangka mengatasi ketegangan, konflik dan frustrasi yang dialami individu setidaknya dapat diatasi dengan melakukan penyesuaian diri. Penyesuaian diri perlu dilakukan oleh setiap individu demi tercapainya keharmonisan antara diri dan tuntutan lingkungan. Darlega dan Janda (1981) menyatakan bahwa efektivitas seseorang dalam menyesuaikan diri dapat dilihat melalui kemampuan individu untuk melihat realitas (perception of reality), fokus pada kehidupan saat ini (living with the past and future), merasa apa yang dilakukan bermakna (meaningful work), pengalaman emosi yang tepat (emotional experience), dan memiliki hubungan sosial yang baik (social relationship).

Penyesuaian diri merupakan suatu proses yang dilakukan individu yang dituntut untuk menyelesaikan, memahami kebutuhan dirinya, ketegangan dan konflik, yang bertujuan untuk mendapatkan keharmonisan dan keselarasan antara tuntutan lingkungan dengan tuntutan dirinya (Kusdiyanti, Halimah, \& Faisaluddin, 2011). Hal tersebut sesuai dengan yang disampaikan Gunarsa (2006), bahwa penyesuaian diri merupakan suatu proses kehidupan setiap individu dari lahir sampai mati, dimana individu akan terus berjuang menyesuaikan diri agar tercipta kesehatan jiwa dan mental.

Penyesuaian diri perlu dilakukan oleh setiap individu, tanpa terkecuali dalam hal ini narapidana. Berdasarkan UU nomor 12 tahun 1995 pasal 1 ayat 7, bahwa narapidana adalah orang yang berstatus penghuni lembaga pemasyarakatan yang hilang kebebasannya. Sementara Kamus Besar Bahasa Indonesia mendefinisikan narapidana sebagai orang yang bersalah dan menjalani hukuman sesuai dengan perbuatan yang telah dilakukan. Pada saat individu berubah status menjadi seorang narapidana, maka sejak saat itu mereka harus melakukan penyesuaian diri dengan kehidupan di lingkungan baru, dan hal tersebut dimulai saat pertama kali mereka memasuki Rumah Tahanan (Rutan). Selama berada di Rutan, narapidana dituntut untuk menyesuaikan diri dengan kondisi dan situasi, penghuni, lingkungan, termasuk dengan aturan-aturan yang ditetapkan oleh Rutan. Sementara, ketidakmampuan narapidana menyesuaikan diri dengan semua hal yang ada di Rutan akan berdampak pada kesehatan fisik ataupun psikologisnya.

Secara umum permasalahan psikologis yang dialami narapidana ditunjukkan mulai dari pertama kali individu divonis oleh pengadilan. Adapun gejala psikologis yang dialami sebagian individu diantaranya merasakan khawatir, cemas, takut, putus asa, marah, terkucil, perasaan tidak percaya terhadap keputusan yang ditetapkan pengadilan, ataupun untuk berada di balik jeruji penjara tersebut. Beberapa individu pada akhirnya menjadi enggan untuk melakukan aktivitas karena kekhawatiran akan stigma atau pandangan negatif masyarakat tentang narapidana.

Menurut Schneiders (2000) seseorang dapat dikatakan mempunyai penyesuaian diri baik (well-adjusted person) jika dapat melaksanakan respon-respon yang tepat, efisien, memuaskan dan sehat. Sebaliknya, seseorang diaktakan memiliki penyesuaian diri yang 
buruk jika seseorang tidak dapat menyelesaikan berbagai permasalahan yang dihadapinya dan menimbulkan perasaan cemas pada dirinya. Schneiders juga menjelaskan bahwa penyesuaian diri dapat berupa proses adaptasi, dan proses adaptasi terrsebut dapat dipengaruhi oleh pemahaman narapidana terhadap nilai-nilai keberagamaan dan kebermaknaan hidup, sedangkan proses adaptasi dengan lingkungan membutuhkan dukungan sosial dari orang-orang di sekitarnya.

Keberagamaan atau religiusitas meliputi berbagai macam sisi atau dimensi yang bukan hanya terjadi ketika seseorang melakukan perilaku ritual (beribadah), tetapi juga melakukan aktivitas lain yang didorong oleh kekuatan supranatural (Ancok \& Suroso, 2011). Glock dan Stark (dalam Ancok dan Suroso, 2011) menjelaskan dimensi religiusitas yang terdiri dari keyakinan ideologis, praktik agaman, pengalaman religius, pengetahuan agama, dan konsekuensi. Bastaman (2007) menyatakan bahwa makna hidup berkaitan dengan hal yang dianggap penting dan berharga, serta mampu memberikan nilai khusus bagi individu, sehingga layak dijadikan sebagai tujuan dalam kehidupan. Tujuan hidup dalam hal ini berhubungan dengan sesuatu yang akan dicapai dan dipenuhi. Rook, (dalam Smet, 1994) berpendapat bahwa dukungan sosial sebagai satu diantara fungsi pertalian atau ikatan sosial. Dukungan sosial sendiri timbul dikarenakan adanya persepsi individu akan adanya seseorang yang akan membantu bilaman terjadi keadaan atau kejadian yang dinilai dapat menimbulkan masalah, dalam hal ini bantuan tersebut dirasa mampu mendorong perasaan positif, serta harga diri individu. Sesuai dengan yang disampaikan Cohen dan Wills (dalam Fisher, Bishop, Levitt-Gilmour, Cappello, Ashenberg, \& Newman, 1994) bahwa dukungan sosial sebagai pertolongan dan dukungan yang diperoleh seseorang dari interaksinya dengan orang lain.

Berdasarkan pemaparan sebelumnya maka tujuan dari penelitian ini adalah untuk menguji secara empiris korelasi antara religiusitas, kebermaknaan hidup, dan dukungan sosial dengan penyesuaian diri narapidana. Hasil dari penelitian ini diharapkan memberikan kontribusi bagi pengembangan ilmu khsusunya di bidang psikologi sosial. Selain itu, dengan mengetahui faktor yang relevan dalam mempengaruhi penyesuaian diri narapidana, maka dapat menjadi rekomendasi bagi banyak pihak untuk mempertimbangkan hasil penelitian ini demi tercapainya keharmonisan antara diri narapidana dan tuntutan lingkungannya. Oleh karena itu, hipotesis yang diajukan dalam penelitian ini terdapat korelasi antara religiusitas, kebermaknaan hidup, dukungan sosial dengan penyesuaian diri narapidana.

\section{Metode}

Metode yang digunakan pada penelitian ini menggunakan metode kuantitatif desain korelasi. Subjek penelitian ini sejumlah 246 orang yang berstatus narapidana yang berada di Rutan Kelas 1 Surakarta, Jawa Tengah. Sesuai dengan yang disampaikan Sekaran (2006) bahwa penentuan jumlah sampel yang ideal adalah 10 kali jumlah variabel yang akan diteliti. Pada penelitian ini menggunakan 4 variabel, seharusnya membutuhkan 400 orang subjek penelitian, namun keterbatasan jumlah subjek penelitian (terdapat 246 orang narapidana) yang membuat peneliti memilih menggunakan seluruh narapidana yang ada di Rutan Kelas 1 Surakarta, Jawa Tengah, sebagai subjek penelitian. Penelitian ini tidak melakukan uji coba skala secara terpisah, namun uji keajegan skala dilakukan berdasar data yang diperoleh pada saat penelitian, sedangkan uji validitas skala sudah dilakukan sebelumnya dengan menggunakan penilaian rater (expert judgment) dengan formula dari Aiken's $V$.

Adapun instrumen pengukuran yang digunakan dalam penelitian ini berupa skala. Model penyekoran yang digunakan merupakan modifikasi dari skala Likert, dengan menghilangkan pilihan jawaban di tengah sehingga hanya terdapat 4 alternatif jawaban. Hal ini ditempuh dengan mempertimbangkan pendapat Hadi (1991) yang menyatakan bahwa meniadakan jawaban di tengah dengan tujuan (1) mengurangi makna ganda yang terdapat dalam pilihan jawaban yang berada di tengah, (2) mengurangi kecenderungan untuk menjawab di tengah, 
dan (3) mendorong responden untuk memberikan jawaban lebih pasti.

Pengambilan data dengan instrumen skala psikologi yang terdiri atas: 1) Skala penyesuaian diri, menggunakan skala yang dikembangkan oleh Kumalasari dan Ahyani (2012) dengan menggunakan aspek-aspek self-knowledge, self-acceptance, self-control dan satisfaction. 2) Skala religiusitas, disusun berdasarkan aspek yang dikembangkan Huber dan Huber (2012) yang meliputi: pengetahuan, praktek pribadi, praktek umum, pengalaman dan keyakinan. 3) Skala kebermaknaan hidup, berdasarkan aspek yang dikembangkan oleh Bastaman (2007) yaitu: kebebasan untuk berkehendak, kehendak untuk hidup bermakna dan makna hidup. 4) Skala dukungan sosial, menggunakan modifikasi dari Handono dan Bashori (2013) yang meliputi: dukungan emosional, dukungan instrumental, dukungan informasi dan dukungan penghargaan.

Hasil penilaian rater (expert judgement) untuk skala penyesuaian diri menunjukkan nilai V bergerak dari 0,312-0,812, dan koefisien reliabilitas (alpha cronbach) sebesar 0,738; skala religiusitas menunjukkan nilai $\mathrm{V}$ bergerak dari 0,481-0,937, dengan koefisien reliabilitas (alpha cronbach) sebesar 0,818; skala kebermaknaan hidup menunjukkan nilai V sebesar 0,50,812, dengan koefisien reliabiltas (alpha cronbach) sebesar 0,676; selanjutnya skala dukungan sosial menunjukkan nilai $\mathrm{V}$ sebesar 0,625-0,875, dengan koefisien reliabilitas (alpha cronbach) sebesar 0,730.

Sebelum melakukan uji hipotesis, peneliti melakukan uji asumsi terlebih dahulu. Uji asumsi yang penulis lakukan adalah uji normalitas sebaran data pada variabel tergantung yaitu penyesuaian diri, dan uji linieritas antara (1) religiusitas dan penyesuaian diri, (2) kebermaknaan hidup dengan penyesuaian diri, dan (3) dukungan sosial dengan penyesuaian diri. Uji normalitas sebaran data dengan menggunakan Kolmogorov-Smirnov, menunjukkan nilai koefisien sebesar 0,056 dan $p=0,063(p>0,05)$ yang menunjukkan bahwa sebaran data penyesuaian diri memenuhi distribusi normal. Hasil uji linieritas dapat dilakukan dengan melihat taraf signifikansi pada nilai $\mathrm{F}$ dari deviation from linearity atau membandingkan nilai F hitung dengan $F$ tabel. Hasil uji lineritas antara (1) religiusitas dan penyesuaian diri menunjukkan nilai $\mathrm{F}=2,009$ dengan $\mathrm{p}=0,001$, dan nilai Ftabel=1.72, yang menunjukkan bahwa korelasi antara religiusitas dan penyesuaian diri bersifat linier, (2) kebermaknaan hidup dengan penyesuaian diri menunjukkan nilai $\mathrm{F}=1,538$ dengan $\mathrm{p}=0,057$, dan nilai Ftabel=1.71, yang menunjukkan korelasi kebermaknaan hidup dan penyesuaian diri bersifat linier; dan (3) dukungan sosial dengan penyesuaian diri menunjukkan nilai $F=2,269$ dengan $p=0,001$, dan nilai Ftabel=1,71 yang menunjukan bahwa sebaran data dukungan sosial dan penyesuaian diri bersifat linier. Hasil uji asumsi tersebut sebagai landasan pemilihan teknik analisis dengan menggunakan parametrik; sedangkan teknik analisis data yang digunakan untuk menguji hipotesis berupa analisis regresi berganda (multiple regression analysis) dengan SPSS 21 for Windows.

\section{Hasil}

Hipotesis pertama yang diajukan dalam penelitian ini bahwa terdapat korelasi antara religiusitas, kebermaknaan hidup, dukungan sosial dan penyesuaian diri, diuji dengan menggunakan analisis regresi berganda. Hasil uji hipotesis menunjukkan nilai koefisien korelasi $R=0,740$, dengan $p=0,000(p<0,001)$ yang dapat diartikan bahwa terdapat korelasi yang sangat signifikan antara religiusitas, kebermaknaan hidup, dukungan sosial dan penyesuaian diri narapidana. Dimana variabel religiusitas, kebermaknaan hidup dan dukungan sosial secara simultan mempunyai korelasi yang sangat signifikan dengan penyesuaian diri. Sumbangan efektif dari variabel religiusitas, kebermaknaan hidup, dukungan sosial terhadap penyesuaian diri sebesar $60,6 \%$, sementara sisanya meupakan sumbangan faktor lain yang belum diungkap, seperti keadaan fisik, pengalaman, emosi, belajar, dan lain sebagainya.

Hasil uji hipotesis kedua, dilakukan dengan melihat nilai hasil analisis korelasi parsial 
antara religiusitas dengan penyesuaian diri yang menunjukkan nilai rx1y-x2x3=0,457, dengan $\mathrm{p}=0,000(\mathrm{p}<0,01)$. Hasil tersebut menunjukkan adanya korelasi positif dan sangat signifikan antara religiusitas dengan penyesuaian diri narapidana dengan mengendalikan kebermaknaan hidup dan dukungan sosial, sehingga hipotesis kedua diterima. Hasil uji hipotesis ketiga, dilakukan dengan melihat nilai hasil korelasi parsial antara kebermaknaan hidup dengan penyesuaian diri yang menunjukkan nilai $r \times 2 y-x 1 x 3=0,164$, dengan $p=0,000$ $(\mathrm{p}<0.01)$. Hasil tersebut menunjukkan adanya korelasi positif yang sangat signifikan antara kebermaknaan hidup dengan penyesuaian diri dengan mengendalikan religiusitas dan dukungan sosial, sehingga hipotesis ketiga diterima. Hasil uji hipotesis keempat, dilakukan dengan melihat nilai hasil korelasi parsial antara dukungan sosial dengan penyesuaian diri yang menunjukkan nilai $r \times 3 y-x 1 \times 2=0,545$; signifikansi=0,000 $(\mathrm{p}<0.01)$. Berarti terdapat korelasi positif dan sangat signifikan antara dukungan sosial dengan penyesuaian diri narapidana dengan mengendalikan religiusitas dan kebermaknaan hidup, sehingga hipotesis keempat diterima.

Berdasarkan hasil analisis diketahui variabel religiusitas mempunyai rerata empirik sebesar 104,81 dan rerata hipotetik sebesar 90 yang berarti religiusitas tergolong tinggi. Dari jumlah 246 subjek, terdapat 24 subjek $(9,8 \%)$ memiliki religiusitas tergolong sangat tinggi. 160 subjek (65\%) memiliki religiusitas tergolong tinggi, 61 subjek $(24,8 \%)$ memiliki religiusitas tergolong sedang dan 1 subjek $(0,4 \%)$ memiliki religiusitas rendah (berdasar 5 kategori, sangat tinggi, tinggi, sedang, rendah dan sangat rendah). Variabel kebermaknaan hidup diketahui memiliki nilai rerata empirik sebesar 57,20 dan rerata hipotetik sebesar 45 berarti kebermaknaan hidup tergolong sedang. Dari jumlah 246 subjek penelitian, terdapat 29 subjek (11,8\%) memiliki kebermaknaan hidup tinggi, 129 subjek (52,4\%) memiliki kebermaknaan hidup sedang, 87 subjek $(35,4 \%)$ memiliki kebermaknaan hidup rendah, ada 1 subjek $(0,4 \%)$ memiliki kebermaknaan hidup sangat rendah (berdasarkan 5 kategori, yaitu sangat tinggi, tinggi, sedang, rendah, sangat rendah). Variabel dukungan sosial diketahui memiliki nilai rerata empirik 62,54 dan rerata hipotetik sebesar 57,5 berarti dukungan sosial tergolong sedang. Dari jumlah 246 subjek penelitian, terdapat 39 subjek $(15,8 \%)$ memiliki dukungan sosial tinggi, ada 190 subjek $(77,2 \%)$ memiliki dukungan sosial sedang, 16 subjek $(6,6 \%)$ memiliki dukungan sosial rendah, dan 1 subjek $(0,4 \%)$ memiliki dukungan sosial sangat rendah. Adapun variabel penyesuaian diri diketahui nilai rerata empirik 67,93 dan mean hipotetik 62,5 berarti penyesuaiann diri tergolong sedang. Dari 246 subjek penelitian, terdapat 110 subjek $(44,7 \%)$ memiliki penyesuaian diri tinggi, 136 subjek $(55,3 \%)$ memiliki penyesuaian diri sedang.

\section{Pembahasan}

Hipotesis pertama yang berbunyi terdapat korelasi antara religiusitas, kebermaknaan hidup, dan dukungan sosial dengan penyesuaian diri narapidana, dapat dibuktikan dalam penelitian ini. Hasil penelitian ini mendukung hasil penelitian yang telah dilakukan oleh para peneliti sebelumnya tentang penyesuaian diri. Hasil penelitian sebelumnya yang menjelaskan faktor-faktor yang berkorelasi dengan penyesuaian diri diantaranya kebermaknaan hidup (Romadhoni \& Setyawati, 2013), religiusitas (Nadzir \& Wulandari, 2013; Hasan \& Handayani, 2014; Sasmita \& Rustika, 2015; Lestari \& Indrawati, 2017), dan dukungan sosial (Rahma, 2011; Kumalasari \& Ahyani, 2012; Hasan \& Handayani, 2014; Mahmudi \& Suroso, 2014). Hal ini didukung dengan sumbangan efektif sebesar $60,6 \%$, yang mana dapat dikatakan relatif besar. Hasil penelitian ini menunjukan bahwa religisuitas, kebermaknaan hidup dan dukungan sosial merupakan prediktor bagi penyesuaian diri narapidana.

Hasil penelitian ini membuktikan bahwa keberhasilan penyesuaian diri pada narapidana didukung oleh religiusitas, kebermaknaan hidup dan dukungan sosial. Narapidana mampu menerima kondisinya karena dapat memaknai pengalamannya selama di Rutan sebagai hal 
yang perlu diambil hikmahnya dan meningkatkan religiusitasnya (semakin rutin dan rajin mengerjakan sholat), yang tidak terlepas dari dukungan orang-orang di sekitarnya baik keluarga, sesama penghuni rutan, maupun para petugas di rutan. Penyesuaian diri para narapidana sebagian besar tergolong sedang (55,3\% dari 246 orang), dan 44,7\% tergolong tinggi. Informasi ini menunjukkan bahwa secara umum, para narapidana di rutan yang menjadi subjek penelitian ini masih tergolong dapat diperbaiki. Perlakuan yang tepat dapat meningkatkan penyesuaian diri narapidana. Hasil penelitian ini mendukung penelitian awal yang sudah peneliti lakukan, sekaligus mendukung pendapat Schneiders (2000) bahwa penyesuaian diri merupakan proses adaptasi individu yang melibatkan proses mental dan perubahan perilaku untuk memenuhi kebutuhan diri, menghindari ketegangan, kekecewaan dan konflik agar tercapai hubungan yang harmonis antara diri pribadi dengan lingkungan.

Proses adaptasi bersifat dinamis (Mu'tadin, 2002), dilakukan untuk memenuhi salah satu kebutuhan psikologis berupa rasa aman dan nyaman karena berusaha menghindari konflik, bersedia menerima diri sendiri, menikmati hidup serta aktif dalam kegiatan sosial di lingkungannya. Dengan demikian dapat diketahui bahwa penyesuaian diri melibatkan faktor internal dan eksternal. Schneider (2000) menyatakan bahwa faktor dari dalam diri individu ditandai oleh self-knowledge (self-insight) yang menunjukkan bahwa individu memahami kelemahan dan kelebihan yang dimilikinya dan secara sadar berusaha menerima kelemahan yang dimilikinya; self-acceptance yang menunjukkan bahwa individu sudah mengenali diri, bersifat realistis dan bersedia menerima dirinya; self-development dan self-control yang menunjukkan bahwa individu mampu mengelola emosi, impuls, dorongan, pemikiran, dan mengarahkan perilaku agar sesuai dengan tuntutan lingkungan. Proses mengelola emosi, impuls, dorongan, pemikiran dan perilaku yang dilakukan secara terus menerus dan sesuaai dengan tuntutan lingkungan menyebabkan individu mampu berpikir secara matang sehingga mampu menerima kegagalan dengan hati lapang. Faktor dari dalam diri yang tidak kalah penting berupa self-satisfaction yang ditunjukkan oleh kepuasan terhadap apa yang dijalani dan dapat mengambil hikmah dari pengalaman; sedangkan faktor eksternal yang signifikan berupa lingkungan sosial, budaya, masyarakat.

Terbuktinya hipotesis ke dua yang terkait dengan adanya korelasi positif antara religiusitas dengan penyesuaian diri dengan mengendalikan kebermaknaan hidup dan dukungan sosial narapidana menjelaskan bahwa semakin tinggi religiusitas narapidana maka penyesuaian dirinya menjadi lebih positif. Peran religiusitas terhadap penyesuaian diri menjadi penting karena sumbangan efektifnya $24,3 \%$ dan signifikan. Hasil penelitian ini mendukung hasil dari para peneliti sebelumnya yang telah menggunakan dengan sampel yang berbeda, seperti siswa-siswi kelas VII pondok pesantren (Lestari \& Indrawati, 2017), siswa-siswi SMP negeri Pakem (Andriyanti, 2015), maupun santri di pondok pesantren (Nadzir \& Wulandari, 2013).

Individu yang memiliki religiusitas tinggi dapat memberikan nilai dan keyakinan di dalam diri individu sehingga individu merasa memiliki arti, tujuan hidup dan makna hidup untuk menghadapi tekanan dan perubahan yang terjadi dalam dirinya. Hal ini sesuai dengan yang dikemukakan Rahmat (2012), religiusitas merupakan aturan-aturan yang harus dipatuhi dan dijadikan norma oleh penganutnya di dalam menjalani kehidupan sehingga individu mendapatkan kebahagiaan dunia dan akhirat. Narapidana yang menjadi subjek penelitian ini dapat menerima aturan dan norma yang ada yang membuatnya menjadi lebih positif dalam melakukan penyesuaian diri karena religiusitasnya meningkat, bahkan terdapat $74,8 \%$ narapidana yang memiliki religiusitas tergolong tinggi; sedangkan narapidana yang memiliki kategori sedang sebesar 24,8\% dan hanya 0,4\% tergolong rendah. Secara tersirat dapat dimaknai bahwa perlakuan di dalam Rutan sudah sesuai dan mampu meningkatkan religiusitas narapidana.

Hipotesis minor kedua yang juga terbukti menunjukan adanya hubungan positif yang signifikan antara kebermaknaan hidup terhadap penyesuaian diri dengan mengendalikan religiusitas dan dukungan sosial menjelaskan bahwa kebermaknaan hidup memiliki peran 
signifikan pada penyesuaian diri narapidana. Sejauh ini kehidupan di dalam Rutan diasumsikan mampu mendorong narapidana berpikir ulang terhadap makna hidupnya sehingga dapat memaknai pengalaman negatif menjadi pengalaman yang berharga. Hasil penelitian ini mendukung penelitian yang dilakukan oleh Romadhoni dan Setyawati (2013), bahwa memaknai peristiwa atau pengalaman hidup secara lebih positif mampu mendorong seseorang menjadi lebih mudah dalam melakukan penyesuaian diri.

Perbedaan penelitian ini dengan penelitian yang dilakukan oleh Romadhoni dan Setyawati (2013) terletak pada sumbangan efektifnya. Pada penelitian Romadhoni dan Setyawati (2013) sumbangan efektif kebermakanaan hidup terhadap penyesuaian diri sebesar $71,4 \%$ sementara penelitian ini menunjukkan sumbangan efektif kebermaknaan hidup pada penyesuaian diri hanya sebesar 3\%. Perbedaan sumbangan efektif yang relatif jauh ini diasumsikan karena adanya perbedaan dari sisi karakteristik subjek yang digunakan, dimana pada penelitian Romadhoni dan Setyawati (2013), subjek penelitian para penderita sakit ginjal kronis yang secara teori menunjukkan harapan hidup yang lebih kecil dibandingkan orang sehat lainnya. Sementara pada penelitian ini menggunakan subjek yang sehat/ normal (tidak sakit) yang memiliki harapan hidup lebih besar. Subjek penelitian ini sebagin besar masih berusia 25-39 tahun yang masih berada pada usia produktif sehingga cara berpikirnya juga lebih banyak dipengaruhi oleh faktor lingkungan, perubahan sosial, dan perkembangan masyarakat.

Terbuktinya Hipotesis ketiga yang berkaitan dengan adanya hubungan positif yang signifikan antara dukungan sosial dengan penyesuaian diri dengan mengendalikan religiusitas dan kebermaknaan hidup menunjukkan bahwa dukungan sosial berperan secara signifikan terhadap penyesuaian diri narapidana. Pernyataan tersebut ditunjang oleh nilai sumbangan efektif dukungan sosial terhadap penyesuaian diri yaitu sebesar 33,3\%. Pada penelitian ini dukungan sosial sangat dibutuhkan bagi narapidana agar lebih mudah melakukan penyesuaian diri. Dukungan sosial yang dipersepsi secara positif membuat narapidana menjadi lebih yakin dalam menjalani kehidupannya di dalam Rutan dan berharap segera berkumpul kembali dengan keluarga sehingga narapidana berusaha mengikuti aturan, menghindari konflik agar segera keluar dari Rutan. Hasil penelitian ini memperkuat hasil penelitian yang telah dilakukan oleh peneliti sebelumnya yang menunjukkan bahwa dukungan sosial sangat dibutuhkan dalam melakukan penyesuaian diri di lingkungan baru yang dihadapi oleh mahasiswa baru (Sasmita \& Rustika, 2015), penyandang tunarungu di sekolah inklusi (Hasan \& Handayani), penghuni panti asuhan (Kumalasari \& Ahyani, 2012). Dukungan sosial juga diperlukan ketika seseorang melakukan penyesuaian diri dalam belajar (Mahmudi \& Suroso, 2014).

Sumber dukungan sosial berdasarkan hasil dari penelitian ini dan penelitian sebelumnya diperoleh dari keluarga, pengasuh panti asuhan, maupun teman sebaya atau lingkungan tempat individu berada. Sebaran kategorisasi dukungan sosial dalam penelitian ini menunjukkan bahwa terdapat $15,8 \%$ narapidana memiliki dukungan sosial tinggi; $77,2 \%$ narapidana memiliki dukungan sosial kategori sedang; 6,6\% narapidana memiliki dukungan sosial rendah dan 1 narapidana atau 0,4\% memiliki tingkat dukungan sosial sangat rendah. Berdasarkan kategorisasi ini memperlihatkan bahwa masih terdapat peluang untuk meningkatkan dukungan sosial baik dari pihak Rutan maupun keluarga agar para narapidana dapat lebih mudah menyesuaikan diri di dalam Rutan maupun setelah keluar Rutan nantinya.

Dukungan sosial yang dipersepsikan secara positif membuat individu (dalam hal ini adalah narapidana) menjadi lebih mudah menerima kondisinya (self-acceptance), bisa membuatnya berpikir lebih dewasa (self-development) dan bisa mengambil hikmah dari pengalamannya (self-satisfaction) seperti yang dikemukakan oleh Schneider (2000). Perbandingan sumbangan efektif antara religiusitas (24,3\%), kebermaknaan hidup (3\%) dan dukungan sosial (33\%) menunjukkan bahwa dukungan sosial memiliki sumbangan efektif 
yang paling besar bagi penyesuaian diri narapidana. Informasi ini menjelaskan bahwa dukungan sosial sangat diperlukan bagi narapidana agar lebih mudah menyesuaikan diri. Hasil penelitian ini juga mendukung pendapat Schneider (2000).

Pengambilan narapidana di rutan sebagai subjek penelitian membutuhkan perjuangan tersendiri secara teknis di lapangan karena masalah perijinan dan keterbatasan dalam pemilihan subjek penelitian. Apabila hal ini dianggap sebagai keterbatasan penelitian, maka diusulkan pada penelitian selanjutnya untuk lebih luwes dalam menjalin komunikasi dengan pihak rutan sehingga dapat memperoleh subjek penelitian sesuai dengan harapan.

\section{Simpulan}

Penelitian ini membuktikan adanya korelasi yang signifikan antara religiusitas, kebermaknaan hidup, dan dukungan sosial dengan penyesuaian diri narapidana. Hasil penelitian ini menjelaskan bahwa religiusitas, kebermaknaan hidup dan dukungan sosial merupakan prediktor dan hal yang dibutuhkan narapidana untuk melakukan penyesuaian diri di dalam Rutan. Religiusitas yang tinggi, kebermaknaan hidup yang tinggi dan dukungan sosial yang dipersepsikan lebih positif mendorong narapidana mampu memahami apa yang sedang terjadi dan dialaminya, sehingga berusaha menerima kondisinya, mampu mengambil hikmah dari apa yang dialami dan tetap merasa puas meskipun ruang geraknya terbatas.

Sumbangan efektif dukungan sosial menunjukkan nilai yang paling besar dibandingkan religiusitas dan kebermaknaan hidup. Informasi ini menunjukkan bahwa keberhasilan para narapidana dalam melakukan penyesuaian diri sebagian besar ditentukan oleh dukungan sosial. Oleh karena itu, intervensi yang diberikan berupa dukungan sosial akan lebih efektif bagi penyesuaian diri narapidana. Intervensi yang kedua berupa meningkatkan religiusitas dan kebermaknaan hidup.

\section{DAFTAR PUSTAKA}

Andriyanti, N. (2015). Hubungan antara religiusitas dengan penyesuaian diri di sekolah pada siswa SMP Negeri 3 Pakem tahun ajaran 2014/2015. Jurnal Bimbingan dan Konseling, $1-11$.

Ancok, D., \& Suroso, F.N. (2011). Psikologi Islami solusi Islam atas problem-problem psikologi. Yogyakarta: Pustaka Pelajar.

Bastaman, H. D. (2007). Logoterapi: Psikologi untuk menemukan makna hidup dan meraih hidup bermakna. Jakarta: PT. Grafindo Persada.

Darlega, V. J., \& Janda. L. H. (1981). Personal adjustment the psychology of everyday life. (Chapter 1) Illinois: Scott, Foresman and Company.

Fisher Jr, E. B., Bishop, D. B., Levitt-Gilmour, T., Cappello, M. T., Ashenberg, Z. S., \& Newman, E. (1994). Social support in worksite smoking cessation: qualitative analysis of the EASE project. American Journal of Health Promotion, 9(1), 39-75.

Gunarsa, S.D. (2006). Psikologi perkembangan anak dan dewasa. Jakarta: Gunung Mulia.

Hadi, S. (1991). Metodologi research. Yogyakarta: Andi Offset.

Handono \& Bashori. (2013). Hubungan antara penyesuaian diri dan dukungan sosial terhadap stres lingkungan pada santri baru. Jurnal Fakultas Psikolog, 1 (2), 79-89.

Hasan, S. A., \& Handayani, M. M. (2014). Hubungan antara dukungan sosial teman sebaya dengan penyesuaian diri siswa tunarungu di sekolah inklusi. Jurnal Psikologi Pendidikan dan Perkembangan, 3(2), 128-135.

Huber, S., \& Huber, O.W. (2012). The centrality of religiosity scale. Religions, 3, 710-724.

Kamus Besar Bahasa Indonesia. Narapidana. https://kbbi.web.id.

Kumalasari, F., \& Ahyani, L. N. (2012). Hubungan antara dukungan sosial dengan penyesuaian diri remaja di panti asuhan. Jurnal Psikologi: PITUTUR, 1(1), 19-28. 
Kusdiyati, S., Halimah, L., \& Faisaluddin. (2011). Penyesuaian diri di lingkungan sekolah pada siswa kelas XI SMA Pasundan Bandung. Jurnal Humanitas, VIII (2), 171-194.

Lestari, D., \& Indrawati, E. S. (2017). Hubungan antara religiusitas dengan penyesuaian diri pada siswa dan siswi kelas VII Yayasan Pondok Pesantren Futuhiyyah Mranggen Kabupaten Demak. Jurnal Empati. 6 (4).

Mahmudi, M. H., \& Suroso. (2014). Efikasi diri, dukungan sosial, dan penyesuaian diri dalam belajar. Jurnal Psikologi Indonesia, 3(02), 183 - 194.

Mu'tadin, Z. (2002, 25 Juni). Kemandirian sebagai kebutuhan psikologis pada remaja. FTP: http://www.e-psikologi.com/epsi/individual.asp.

Nadzir, A.I., \& Wulandari, N.W. (2013). Hubungan religiusitas dengan penyesuaian diri siswa pondok pesantren. Jurnal Psikologi Tabularasa. 8 (2).698-707.

Rahma, A. N. (2011). Hubungan efikasi diri dan dukungan sosial dengan penyesuaian diri remaja di panti asuhan. Jurnal Psikologi Islam, 8 (2), 231-246.

Rakhmat, J. (2007). Psikologi komunikasi. Bandung: PT. Remaja Rosdakarya.

Romadhoni, M., \& Setyawati, (2013). Hubungan antara penyesuaian diri dengan kebermaknaan hidup pada penderita penyakit ginjal kronik di RSUD Banyumas. Psycho Idea, No.1.

Sasmita, I. A. G. H. D., \& Rustika, I. M. (2015). Peran efikasi diri dan dukungan sosial teman sebaya terhadap penyesuaian diri mahasiswa tahun pertama Program Studi Pendidikan Dokter Fakultas Kedokteran Universitas Udayana. Jurnal Psikologi Udayana. 2 (2).280-289.

Schneiders. (2000). Personal adjustment and mental health. New York: Rinehart and Winston.

Sekaran, U. (2006). Metode penelitian bisnis. Jakarta: Salemba Empat.

Smet, B. (1994). Psikologi kesehatan. Jakarta: PT. Grasindo.

Suharsimi, A. (2006). Prosedur penelitian suatu pendekatan praktek. Jakarta: Rineka Cipta.

Undang-Undang Republik Indonesia nomor 12 Tahun 1995 tentang pemasyarakatan. http://bphn.go.id/data/documents/95uu012.pdf. 